\begin{tabular}{|l|c|c|}
\hline Q19. & \multicolumn{3}{|c|}{$\begin{array}{c}\text { Eurasian Academy of Sciences } \\
\text { Eurasian Education \& Literature Journal } \\
\text { Volume:1 }\end{array}$} & S: $43-58$ \\
\hline
\end{tabular}

\title{
GRADUATE EDUCATION TEACHERS 'ATTITUDES TOWARDS THE REASONS AND CHOOSE THE TEACHING PROFESSION: REVIEW OF THE LITERATURE
}

\section{Elif BAHADIR *}

* Y1ldı Teknik Üniversitesi E-mail: ebahadir@yildiz.edu.tr

Copyright (C) 2015 Elif BAHADIR. This is an open access article distributed under the Eurasian Academy of Sciences License, which permits unrestricted use, distribution, and reproduction in any medium, provided the original work is properly cited.

\begin{abstract}
Today, the knowledge has been disqualified for developments and changes. So, it is the person's own responsibility to follow the changes. The people, especially the teachers will have redounded the qualifications if they follow the knowledge. Today, the postgraduate education comes into questions increasingly on gaining the knowledge and redounded the quality. In this literature review study, reasons for choosing graduate education teachers' attitudes towards the teaching profession have been scrutinized. Although there are some contrasting results according to previous studies, recently researches about teachers to renew themselves, to be aware of the scientific and technological developments and results to be more productive stands out for doing post-graduate education and Graduate education is that prospective teachers have positive attitude.
\end{abstract}

Keywords: Postgraduate Education, Teaching Profession, Attitude

\section{Öğretmen Adaylarının Öğretmenlik Mesleğini Tercih Sebepleri Ve Lisansüstü Eğitime Yönelik Tutumları: Literatür Taraması}

ÖZET: Bilginin, gelişmeler ve değişmeler karşısında hızla eskidiği günümüz dünyasında, değişiklikleri takip etmek bireylerin sorumluluğuna kalmaktadır. Genelde bireyler, özelde öğretmenler bilgiyi takip ettiği sürece, niteliğini arttırmış olacaktır. Günümüzde bilgiye ulaşma ve bilginin niteliğini arttırmada lisansüstü eğitim giderek önem kazanmaktadır. $\mathrm{Bu}$ literatür tarama çalışmasında öğretmen adaylarının öğretmenlik mesleğini tercih sebepleri ve lisansüstü eğitime yönelik tutumlarına yönelik çalışmalar incellenmiştir. Yapılan araştırmalarda farklı sonuçlara ulaşılmasına rağmen son zamanlardaki araştırmalarda öğretmenlerin kendilerini yenileme, bilimsel ve teknolojik gelişmelerden haberdar olma ve daha verimli olmak için lisansüstü eğitim yaptıklarına dair sonuçlar öne çıkmaktadır. Öğretmen adaylarının lisansüstü eğitime dair olumlu tutum sergiledikleri görülmektedir.

Anahtar Kelimeler: Lisansüstü Eğitim, Öğretmenlik Mesleği, Tutum 


\section{Giriş}

Eğitim, en genel anlamıyla istendik davranışları bireye kazandırma sürecidir. Bu sürecin çoğunlukla okul içinde geçmesi, eğitim sisteminin üç temel öğesi olan eğitim programı, öğretmen ve öğrenciyi önemli hale getirmektedir. Öğretmen, eğitim programı ile öğrenciyi karşı karşıya getirme, öğrenciyi akademik ve meslekî açıdan geliştirme, öğrenciyi topluma hazırlama gibi sorumluluklarının bulunması nedeniyle ayrı bir öneme sahiptir. Yaşar (2000)'a göre 'önceleri herkesin yapabileceği bir iş olarak görülen öğretmenlik artık bilimsel akademik ve uzmanlık gerektiren bir meslek olarak kabul edilmektedir' (Akt. Semerci, 2005). Öğretmenlik mesleği kuşkusuz temel ve kapsayıcı özelliği olan bir meslektir. Öğretmenler, her meslek grubundan insanın yetiştirilmesinde rol aldığı gibi bir ülkenin kalkınması, toplumdaki huzur ve sosyal barışın sağlanması, bireylerin sosyalleşmesii, toplumsal hayata hazırlanması, toplumun kültür ve değerlerinin genç kuşaklara kazandırılması ve nitelikli insan gücünün yetiştirilmesini sağlamada da etkindir (Çelikten, Şanal ve Yeni, 2005). Bu yüzden eleştirel pedagogların, öğretmeni bir "aydın" (Giroux, 1988) ya da bir "kültür çalışanı" (Freire, 1998) olarak nitelemeleri tesadüf değildir. Bir ülkede amaçlanan toplumsal kalkınmanın gerçekleştirilmesinde temel araç, kaliteli bir eğitim; eğitimde kalitenin ön koşulu da nitelikli öğretmenlerdir. Bu nedenle, eğitim sistemi içinde görev yapan öğretmenlerin niteliklerini artırmak ve kaliteli öğretmenler yetiştirmek için öğretmen eğitimi programlarının amaçlara ve çağın gereklerine uygun olarak donatılması ve yeni okuryazarlık (bilgi okuryazarlığı) alanlarının öğretmen eğitimi programlarında yer alması gerekmektedir (Adıgüzel, 2007; Şenses, 2007; Güven, 2004).

İyi yetişmiş öğretmenlere sahip olabilmek amacıyla gelişen ve değişen dünyada tüm ülkeler, eğitim sistemlerini ve bu bağlamda öğretmen yetiştirme politikalarını sorgulamayı ve sürekli güncel hale getirmeye çalışmaktadır. Çünkü öğretmen yetiştirme, genel anlamda insan yetiştirme düzeninin temel öğesi ve belirleyicisidir. Öğretmen yetiştirme politikalarının geliştirilmesinde sosyo-ekonomik, sosyo-kültürel ve siyasal gelişmelerin önemli etkisi vardır (Aslan, 2003).

Sağlıklı toplumları oluşturan en önemli unsurlardan birisi, hiç şüphesiz e ğitim sistemi ve bu sistemin etkin bir şekilde işletilmesidir. Bir eğitim sisteminin başarısı ise sistemin temel öğesini oluşturan öğretmenlere ve onların niteliklerine bağlıdır (Çeliköz ve Çetin, 2004).

Eğitim hayat boyu devam ettiği için öğretmenlerin eksikliklerini gidermesi, çağı yakalaması, yeni yaklaşımları öğrenmesi öğretmen eğitimi, üzerinde durulması gereken konulardan birisidir (Yapıc1, 2003).

Geçmişte üniversiteler yüksek nitelikli insan gücünü lisans düzeyiyle yetiştiriyordu. Üniversitelerin işlevi hızla değişen ve artan bilgi birikimi karşısında değişmek zorunda kalmıştır. İstenilen yüksek nitelikli insan gücü artık yüksek lisans ya da doktora düzeyiyle yetiştirilmeye başlanmıştır. Önceleri lisans mezunu olmak ayrıcalıklı salyılırken şimdilerde yüksek lisans ya da doktora öğretimi bireye bir ayrıcalık sağlamaktadır (Güven ve Tunç, 2007). 
Yapılan çalışmalar incelendiğinde Öğretmen adaylarının öğretmenlik mesleğini tercih sebeplerinin arasında lisansüstü eğitim ve akademik açıdan yükselme son ssıralarda görülse de lisansüstü eğitime her alanda olduğu gibi eğitim alanındaki öğretmenlerin ve öğretmen adaylarının da ilgisi son zamanlarda oldukça fazladır. Bu sebeple araştırmamızda öğretmen adaylarının öğretmenlik mesleğini tercih sebepleri, lisansüstü eğitim ve öğretmen adaylarının lisansüstü eğitime yönelik tutumları üzerine yapılan araştırmaların literatür taraması yapılmıştır.

\section{Öğretmen Adaylarının Öğretmenlik Mesleğini Tercih Sebepleri}

Öğretmenlik mesleği kuşkusuz temel ve kapsayıcı özelliği olan bir meslektir. Öğretmenler, her meslek grubundan insanın yetiştirilmesinde rol aldığı gibi bir ülkenin kalkınması, toplumdaki huzur ve sosyal barışın sağlanması, bireylerin sosyalleşmesii, toplumsal hayata hazırlanması, toplumun kültür ve değerlerinin genç kuşaklara kazandırılması ve nitelikli insan gücünün yetiştirilmesini sağlamada da etkindir (Çelikten, Şanal ve Yeni, 2005).

Öğretmenlik mesleğinin bu önemli konumu, öğretmen olmak amaciyla eğitim fakültelerini tercih eden öğrencilerin bu tercihlerinin sebeplerini incelemeyi, sürekli bir çaba olarak karşımıza çıkarmaktadır. Araştırmalar, meslek tercihlerinin ağırlıklı olarak ekonomik etkenlere dayandığına, dolayısıyla kişilerin meslek tercihlerinin, gerçek ilgilerinden farklılaştığına işaret etmektedir (Behymer ve Cockriel, 2005; Kniveton, 2004). Öğretmenlik mesleği için de durum farklı değildir, çünkü yapılan araştırmalar (Bastick,2000; Boz ve Boz, 2008; Papanastasiou ve Papanastasiou, 1998) öğretmenlik mesleğini tercihte dişsal faktörlerin oynadığı role dikkatleri çekmektedir. Önceki çalışmaların bulguları (Bastick, 2000; Boz ve Boz, 2008; Brown, 1992; Chuene, Lubben ve Newson, 1999; Kyriacou ve Coulthard, 2000; Saban, 2003), öğretmen adaylarının meslek tercihlerinin başlıca üç temel kategorideki etkenlere dayalı olarak şekillendiğine işaret etmektedir. Bunlar (1) özgeci gerekçeler (özveriye dayalı); insanlara hizmet etme arzusu, topluma faydalı olma isteği, ülkeye hizmet etme vb., (2) içsel gerekçeler; mesleği sevmek, çocukları sevmek, insianları sevmek, ilgi duymak, yetenekli olduğunu düşünmek vb. ve (3) dişsal gerekçeler; iş garantisi, uzun tatil, sosyal güvence, atanma koşulları vb. olarak ifade edilmiştir. Mesleği tercih gerekçeleri, toplumların birbirinden farklı olan sosyal, kültürel ve ekonomik yapılarından dolayı da değişkenlik göstermektedir. Örneğin, Papanastasiou ve Papanastasiou (1997) tarafindan ABD ve Kıbrıs'ta ilköğretim öğretmen adayları üzerinde gerçekleştirilen bir çalışma; ABD'de içsel, Kıbrıs'ta ise dışsal etkenlerin en güçlü tercih sebebi olarak ifade edildiğini göstermiştir. Genel olarak gelişmiş ve refah düzeyi yüksek olan toplumlarda içsel veya özgeci, henüz gelişmekte olan toplumlarda ise dişsal tercih sebeplerinin daha etkili olduğu görülmektedir (Bastick, 2000). Papanastasiou ve Papanastasiou, (1998) tarafindan Kıbrıs’ta gerçekleştirilen başka bir çalışmanın bulguları, en güçlü tercih sebebi olarak, dışsal bir etken olanı mezuniyet sonrası çabuk atanmayı göstermiştir. Benzer şekilde Bastick (2000), Jamaikalı öğretmen adayları üzerinde dışsal etkenlerin birinci derecede önemli olduğunu, bunu özgeci ve içsel sebeplerin izlediğini saptamış; elde edilen bu bulguların, gelişmekte olan ülkelerdleki eğilimle uyum gösterdiğini dile getirmiştir. Boz ve Boz (2008) Ankara'da iki farklı üniversitede öğrenim gören orta öğretim kimya ve matematik öğretmen adaylarının öğretmenliği tercih etme nedenlerini incelemişler ve dişsal nedenleri en güçlü belirleyici olarak saptarken, bunu içsel 
ve özveriden kaynaklanan nedenlerin takip ettiğini ifade etmişlerdir. Bununla birlikte farklı bağlam ve zamanlarda yapılan diğer çalışmaların farklı sonuçlar verdikleri de bilinmektedir. Saban'ın (2003) yapmış olduğu çalışma, özveri ve dışsal etkenlerin içsel etkenlerden daha baskın olduğuna işaret ederken; Özbek (2007) tarafından yapılan bir çalışma da, kişisel tercih ile ilgili etkenlerin, ekonomik ve sosyal etkenlere göre daha baskın olduğunu göstermiştir.

Ayrıca öğretmenliğin "kadın mesleği”" olarak algılanması ve kadınlar tarafından daha çok tercih edilmesi birçok araştırmada dile getirilmiştir (Foster ve Newman, 2005; Johnston, McKeown ve McEwen, 1999; Saban, 2003; Smedley, 2007). Başta İngiltere olmak üzere yurt dışında yapılan birçok çalışmada bu durum, mesleğin "kadınsılaşması" olarak ifade edilmiştir. Kanada Ontario'da yapılan bir araştırmada, erkek ilkokul öğretmenlerinin oranının onda birin bile altına düştüğü dile getirilmiştir (Parr, Gosse ve Allison, 2008). Dolayısıyla öğretmen yetiştirme programına katılan erkeklerin kendilerini kadınlara ait bir alana girmiş veya kadınlar tarafından olumsuz anlamda etiketlenmiş olarak algılamalarıyla ortaya çıkan psikolojik baskı, araştırma sonuçlarına yansımıştır (Mulholland ve Hansen, 2003). Ülkemizde yapılan çalışmalar (Saban, 2003; Şahin, Çokadar ve Uşak, 2008) sınıf öğretmeni adaylarının yaklaşık üçte ikisinin kadınlardan oluştuğunu göstermektedir. Saban'ın (2003) çalışması, mesleğin kişiliklerine uygun olduğunu düşünme açısından kadınların puanlarının erkeklerin puanlarından anlamlı derecede farklı (daha yüksek) olduğunu ve meslek tercihinde kadınların erkeklere göre özgeci ve içsel gerekçelere daha çok dayandıklarını vurgulamaktadır. Benzer şekilde Johnston ve diğerleri (1999) tarafından İngiltere'de yapılan bir çalışma; öğretmenlik mesleğini tercihte kadınların içsel, erkeklerin ise dışsal faktörlerden daha çok etkilendiğini; "çocuklarla çalışma" ve "maaş faktörü” açısından erkeklerle kadınlar arasında anlamlı bir fark olduğunu göstermektedir. Diğer bir deyişle, kadınlar çocuklarla çalışmayı erkeklere göre daha çok önemserken, erkekler maaş faktörünü kadınlara göre daha çok önemsemişlerdir.

\section{Lisansüstü eğitim}

Güven ve Tunç (2007), Ankara Üniversitesi'nde lisansüstü öğretim gören öğrencilerin akademik sorunlarını belirlemişlerdir. Elde edilen bulgulara göre, yüksek lisans ve doktora öğrencileri en az sorunu "akademik yeterlikler" ile ilgili konularda yaşamaktadırlar. Buna karşın, en fazla sorunu "bireysel olanaklar ve fakülte olanakları” konularında yaşamaktadırlar. Danışmanlık hizmetleri konusunda doktora öğrencileri, yüksek lisans öğrencilerine oranla daha az sorunla karşılaşmaktadırlar. Tüm lisansüstü öğretim öğrencileri "fakültedeki internet ve bilgisayar olanaklarının yetersizliğini” en önemli sorun olarak görmektedirler. Öğrencilerin bireysel olanaklarının ve akademik niteliklerinin kısmen yeterli olduğu, fakültedeki danışmanlık hizmetleri ve fakülte olanaklarının genel olarak yeterli olduğu bulguları elde edilmiştir.

Yine aynı üniversitede Aslan (2007), doktora öğrencilerinin lisansüstü eğitime ilişkin sorunlarını irdelemiştir. Doktora öğrencilerinin akademik sorunları ile ilgili olarak çok katıldıkları altı ifadenin dördü, kütüphanelerden yararlanma konusunda, ikisi öğretimde kullanılan araç-gereçle ilgilidir. Sosyal sorunları ile ilgili olarak çok katıldıkları ifadeler, ailelerine ve arkadaşlarına yeterince zaman ayıramamaları ve kültürel-sosyal etkinliklere 
katılımın güç olmasıdır. Ekonomik sorunları ile ilgili olarak tamamen katıldıkları ifade, lisansüstü öğretim sırasında kitap, kırtasiye, yazım, fotoğraf ve alan çalışmalarının giderleri bütçelerinde önemli bir gider kalemini oluşturması, ekonomik sorunları ile ilgili olarak orta düzeyde katıldıkları ifadeler, lisansüstü öğretim programına devam edebilmek için vazgeçmek zorunda kaldıkları gelirlerin (ücretsiz izin, ek ders ücreti, yol giderleri) ekonomik açıdan kendilerini zorlaması ve işyerindeki yoğunluk nedeniyle, akademik çalışmalarda yeterli çaba gösterilememesidir.

Bakioğlu ve Gürdal (2001), çalışmalarında lisansüstü tezlerde öğrencilerin ve danışmanların karşılaştıkları sorunları araştırmışlardır. Teze yönelik sorunlar; tezlerin tamamına yakını yayınlanmamakta, tezin yazımı sona bırakılmaktadır, tez öğrencisi üniversitenin maddi kaynaklarını tezi için kullanmamakta, sadece bir araştırma yöntemi kullanılmakta, bitirme tezi uzamakta, danışmanlara yönelik sorunlar; danışmanlar yazılı geri bildirim vermemekte, danışman dikte etmekte, uzman eksikliği hissedilmekte, üniversiteye yönelik sorunlar; enstitüler yazılı açıklayıcı ve yardımcı bilgi vermemekte, kütüphaneler yetersiz bulunmaktadır. Son olarak enstitüler, tez danışmanlığı konusunda eğitimi olmayanlara seminer düzenlemesi, tez konusu belirlendikten sonra ve tez önerisinin enstitüye verilmesinden sonra, konuya en uygun danışman eşleştirmesinin yapılması gibi önerilerde bulunulmuştur.

Kuzu ve Becit (2007), öğretmenlerin lisansüstü eğitimde karşılaştıkları sorunları belirleyip çözüm önerileri sunmuşlardır. Veriler, yarı yapılandırılmış görüşmelerden toplanmıştır. Yapılan görüşmelerin analizleri doğrultusunda öğretmenlerin lisansüstü eğitimde karşılaştıkları sorunları; görev yapmakta oldukları kurumlarından ve üniversiteden kaynaklanan sorunlar diye gruplandırmışlardır. Öğretmenlerin kurumlarına yönelik karşılaştıkları sorunların başında; okul yönetiminin olumsuz tutumu ve zaman konusu gelmektedir. $\mathrm{Bu}$ sorunlara yönelik getirilen çözüm önerileri; idarecilerin yetkilerinin belirlenmesi, ders saatlerinin ayarlanmasıdır. Öğretmenlerin üniversiteye yönelik karşılaştıkları sorunların başında; izin problemi nedeniyle derse devam, yeterli danışmanlık hizmetlerinin alınamaması gelmektedir. Bu sorunlara yönelik getirilen çözüm önerileri; ders programlarının düzenlenmesinde öğretmenlerinin görüşlerinin alınması (hafta sonlarına ders konulması, ikinci öğretim lisansüstü eğitim programlarının açılması, derslerin internet üzerinden verilmesi... vb) ve yeterli danışmanlık hizmetinin sağlanmasıdır.

Turgut (1987), “Eğitimde Lisansüstü Eğitim” adlı çalışmasında lisansüstü eğitim konusundaki problemleri ortaya koyup önerilerde bulunmuştur. Aynı akademik dereceyi veren lisansüstü eğitim programlarının akademik yük bakımından farklı standartlara bağlı olmasının savunulacak bir yanı olmadığını, lisansüstü eğitimin lisansını tamamlayan herkese açık olamayacağını, bu konu eğitim alanındaki lisansüstü eğitimin hangi lisansa dayanacağı sorununu akla getirdiğini belirtmiştir. Öneri olarak; bir lisansüstü programı desenlendikten sonra o programa taban olabilecek lisans programlarının muhteva analiziyle ulaşılabileceğini belirtmiştir. Araştırmacı, son olarak öğretmenlik ve eğitim lisansları, tercihler sıralamasının sonlarına düştüğünü bu problemin çözümüne az sayıdaki yetenekli kişiyi yüksek lisans programlarına alıp, mezunların hepsine doktora yaptırmak ya da yüksek lisans programlarına 
doktora düzeyindeki ihtiyaçtan fazlasını alıp, mezunlar arasından en yeteneklileri doktora programlarına seçmek şeklinde önerilerde bulunmuştur.

Çelik (2007), lisansüstü eğitime geçiş kapısının tasarımı ve gerçekleştirilmesi konusunu araştırmışıı. Etkin ve kolay kullanımlı bir lisansüstü eğitime geçiş kapısının (portal) tasarımı ve gerçekleştirilmesi, özellikle ülkemizde uzaktan öğretim yapma amacı olan kurumlara kendi ihtiyaçları, özellikleri ve hedefleri doğrultusunda bir uzaktan öğretim sistemi geliştirmede önemli bir başvuru kaynağı olacağı sonucuna varılmıştır.

Bümen (2006), çalışmasını Ege Üniversitesi'nde doktora eğitimi yapan ve Gelişim ve Öğrenme ile Öğretimde Planlama ve Değerlendirme derslerini alan 69 öğrenci ve derslerin sorumlusu olan 4 öğretim üyesi üzerinde yürütmüştür. Çalışasının amac1; bu derslerin bilişsel ve duyuşsal hedeflere ne derece ulaştı̆ıını belirleyerek, konuylla ilgili öğrenci ve öğretim üyelerinin görüşlerini değerlendirmektir. Her iki dersin $\% 65$ düzeyinde başarı sağladığı, öğrencilerin derslere yönelik tutumlarının dönem başından sonuna doğru olumlu yönde değiştiği, öğrenciler ders aldıkları öğretim üyelerini öğretim ve iletişim becerileri bakımından çok beğendiği ve dersleri yararlı gördüğü, derslerde sunum yapmaktan ve sınav olmaktan memnun olmadıkları bulgularına ulaşılmıştır. Bümen, son olarak, boylamsal araştırmalarla mezun öğrencilerin öğretim elemanı olduklarında, bu derslerde öğrendikleri bilgi, tutum ve becerileri ne oranda ve nasıl kullandıkları araştırılabileceği önerisinde bulunmuştur.

Demir (2007), lisansüstü eğitimde ders aşamasını tamamlayan 50 öğrenci ile çalışasını yürüterek; öğrencilerin eğitim-öğretim sürecinden beklentileri ve beklentilerinin gerçekleşme düzeyini araştırmıştır. Öğrencilerin, lisansüstü eğitime başvurudaki beklentileri üç ana tema altında toplanmıştır: Ekonomik, kariyer ve diğer beklentiler (tez ve bilgiye ulaşma, teoripratik birlikteliği). Lisansüstü öğrenim gören öğrencilerin büyük çoğunluğu eğitim masraflarına yönelik beklentilerini dile getirirken; daha iyi bir iş ile ekonomik rahatlığa kavuşacaklarını düşünenler ve vasıflı bir eleman olmak ile birlikte üniversitede kariyer ve farklı iş firsatları da yakalayabileceklerini düşünmektedirler. Ders sürecinin beklentileri karşılaması ile ilgili öğrencilerin çoğunluğu kariyer, akademik gellişme ve ilerleme olanaklarına dair olumlu görüşe sahipken, lisans derslerini tekrar olanağı, araştırma-proje hazırlama, ders ve içeriklerine dair memnuniyet hissetmektedirler. Ders sürecinin beklentileri karşılaması ile ilgili olumsuz görüşe sahip öğrencilerin çoğunluğu ise derslerin lisans derslerinin tekrarı olduğunu ve araştırmaya yöneltmediğini düşünmektedirler. Öğrencilerin çoğunluğu, lisansüstü eğitimin iş bulma şansını artırdığını, alanında uzmanlaşmanın bir avantaj ve tercih nedeni olduğunu düşünmektedirler. Üniversitelerin; lisans eğitimi boyunca öğrencileri bir üst eğitim kademesine hazırlamak adına, danışmanlık birimleri oluşturmaları ve bu birimleri uzman kadrolarla desteklemeleri önerilmektedir.

Burgaz ve Şentürk (2007), yüksek lisans tez danışmanlarının iletişim davranışlarına ilişkin danı̧̧man ve danışan görüşlerini anket metoduyla belirlemeye çalışmışlardır. Yüksek lisans tezi yöneten danışmanların kendi iletişim davranışlarına iliş̧in danışman ve öğrenci görüşleri arasında fark olduğunu ve öğrencilerin bu konuda olumsuz görüşe sahip olduklarını 
belirtmişlerdir. Öneri olarak; tez sürecindeki görüşmelerin randevu sistemine göre işlemesinin sağlanması gerektiğini söylemişlerdir.

Tuzcu (2003), lisansüstü öğretim için yurt dışına öğrenci gönderilmesinin planlanmasını ve karşılaşılan sorunları araştırmıştır. Yurt dışına öğrenci göndermede, hedleflere "tamamıyla" ulaşılamadığı, yurt dışına gönderilecek öğrencileri seçme sınavı "tamamıyla yeterli ve objektif" düzeyde olmadığı, yurt dışına gönderilen öğrencilerin, kendilerine verilen (mevzuatta belirtilen) sürede öğrenimlerini tamamlama düzeyi \% 80 dolaylarında olduğu, öğrencilerin yurt dışında başarısız olmalarının temel nedeni, yabancı dil bilgilerinin yetersiz olduğu sonuçlarına ulaşmıştır.

Akpınar (2003), İstanbul'daki öğretmenlerin yeni bilgi teknolojileri kullanımında yükseköğretimin etkisini araştırmıştır. Yükseköğrenimini metropollerde bitiren öğretmenler sınıftaki öğretim etkinlikleri dışında kalan eğitim amacıyla yapmakta olduğu işlerde bilgisayarı yükseköğretimini Doğu, Güney Doğu ve iç yörelerdeki kentlerde bitirenlerden daha sık kullandıklarını, yükseköğrenimini sahil kentlerinde bitiren öğretmenler sınıftaki öğretim etkinlikleri dışında kalan eğitim amacıyla yapmakta olduğu işlerde bilgisayarı yükseköğrenimini, iç yörelerdeki kentlerde bitirenlerden daha sık kullandıklarını belirtmişlerdir. Yükseköğretimini metropoller (İstanbul, Ankara, İzmir, Bursa, Adana, Gaziantep) ve sahil kentlerinde bitiren öğretmenler internet kaynaklarının sınıf içi ve dışı ders etkinlikler bağlamında kullanmada Doğu, Güney Doğu ve iç yörelerdeki kentlerde yükseköğretimini bitiren öğretmenlerden kendi lehlerine farklı olduğunu belirtmiştir.

Bülbül (2003), çalışmasında, öğretim üyelerinin lisansüstü öğretime öğrenci seçme süreciyle ilgili uygulanmakta olan süreçten vazgeçilerek, üniversitelerin kendilerinin hazırlayacağı bir sınav sisteminin geliştirilmesi gerektiği, eğer merkezi bir sınav yapılacaksa bunun başarı puanındaki ağırlığının çok düşük olması, seçim sürecinde eski uygulamada olduğu gibi yazılı ve mülakatın birlikte kullanılması gerektiği görüşlerini paylaştıklarını belirtmiştir. Ayrıca öğretim üyelerinin görüşleri doğrultusunda lisansüstü öğretim için hazırlık aşamasına daha fazla önem verilmesi gerektiği önerisinde bulunulmuştur.

Çıkrıkçı-Demirtaşlı (2002), üniversiteler lisansüstü eğitim programına öğrenci kabul ederken hangi ölçütleri ve nasıl kullandıklarına yönelik bir çalışma yapmışlardır.

Alhas (2006), Türkiye'deki lisansüstü eğitim sürecindeki Milli Eğitim Bakanlığı çalışanı öğretmenlerinin, lisansüstü eğitimde kazanılan beceriler, lisansüstü eğitimin işlevi ve devam edilen program ve dersler konusundaki görüşlerini anket yoluyla belirlemeye çalışmıştır. Öğretmenlerin tümünün bu hususlara yüksek seviyede katılmaları yüksek lisans programlarının öğretmenlerin becerilerini arttırıp onların kişisel gelişimlerini arttırabileceklerini göstermiştir. Öğretmenler derslerde öğrenilen bilgileri alanlarında etkin kullandıklarını belirtmişlerdir. Öğretmenler eğitim görmekte oldukları programları değerlendirdiklerinde derslerin içeriğinin lisansın tekrarı olmadığını, alanla ilgili yeniliklerin derslere yansıtıldığını, derslerin mesleki gereksinimi karşılayabildiğini ve verilen eğitimin bilim adamı yetiştirmeye temel oluşturabilecek nitelikte olduğunu belirtmişlerdir. Kadınların daha fazla beklenti içinde ve seçici olduğu saptanmıştır. Eğitim görülen program hakkında 
erkeklerin kadınlara oranla daha yüksek düzeyde derslerin içerik olarak gerektiği kadar etkin olmadığ1 düşüncesindeler.

Genel olarak incelenen araştırmalarda, lisansüstü eğitimde karşılaşılan akademik sorunlara ve danışmanlık hizmetlerinin niteliğine üniversite, öğrenciler, öğretmenler, danışmanlar ve öğretim üyeleri açısından değinilmiş veya bu sorunların bazı değişkenlere göre (cinsiyet, anabilim dalı, ders-tez aşaması... vb) anlamlı fark oluşturup oluşturmadığı, öğrencilerin ve üniversitelerin bu sorunlara yönelik getirebileceği çözüm önerileri, lisansüstü eğitim yapan öğrencilerin beklentileri ve beklentilerinin karşılanma düzeyi, öğretim üyelerinin lisansüstü öğretime öğrenci seçme sürecine ilişkin görüşleri, lisansüstü eğitime öğrenci kabul edilirken hangi ölçütlerin nasıl kullanıldığı, lisansüstü eğitim yapmakta olan Milli Eğitim Bakanlığı öğretmenlerinin lisansüstü eğitime bakış açıları, kazandıkları beceriler araştırılmıştır.

\section{Öğretmen Adaylarının Öğretmenlik Mesleğine ve Lisansüstü Eğitim Yapmaya Yönelik} Tutumlarl

Bireyleri çeşitli alanlara hazırlama amacıyla verilen eğitimde, mesleği seçen ve o meslek doğrultusunda eğitim alan kişilere gelecekte o mesleğe özgü davranışları gösterebilmesi için gerekli olan bilgiler, duygular ve beceriler kazandırılmaya çalış1lır. Mesleki eğitimde bir anlamda bireylerin gelecekteki davranışlarını belirlemeye yönelik bir eğitim verilir. Öğretmen yetiştirme programlarında da öğrencilere kazandırılacak bilgiler, duygular ve becerilerle onların mesleki yaşamdaki davranışlarının daha etkili olması sağlanmaya çalışılmaktadır. Öğretmenlik mesleğini uygulayacak olan bireylerin bu mesleğin gerekliliklerini daha etkili biçimde yerine getirebilmelerinin koşullarından biri de mesleğe yönelik tutumlarının olumlu olmasıdır. Öğretmenlik programlarında öğrenim görmekte olan öğrencillerin mesleğe karş1 tutumlarının belirlenmesi bu öğrencilere yetişme sürecinde ne tür tutumların kazandırılması gerektiği konusunda bilgi verecektir.

Smith (1968)'e göre “tutum, bir insana atfedilen, onun psikolojik bir nesneyle ilgili düşünce, duygu ve davranışlarını bir düzen içinde oluşturan bir eğilimdir” (Akt. Arkon2005, s.159). Bireyin sahip olduğu tutum onun eğitim, meslek seçimi ve yaşam tarzı gibi önemli konularda verdiği kararları etkilemektedir (Baron and Byrne, 1979). Özellikle bir mesleğe yönelik olarak geliştirilen tutum, bireyin o meslekteki başarısının en önemli belirleyicisidir (Çakır, 2005). Bu nedenle mesleğini sevmeyen birinin mesleğinde başarılı olamayacağı kanısı toplumda oldukça yaygindir.

Çalışma yaşamının bireyi, bireyin de çalışma yaşamını etkilediği bir gerçektir. Ancak sahip olunan işin kişi için ifade ettiği anlam ve birey-iş ilişkisinin temelinde ortaya çıkan olumluolumsuz tutumlar ya da duygular, çalışan kişinin işine ve kurumuna yönelik göstereceği tutumları etkilemektedir. Bu tutumların olumlu yönde olması bireyin sağlığı ve kurumun başarısı ile sonuçlanır (Aytaç 2005; Kuşdil vd., 2003). Diğer bir ifadeyle, işe ve kuruma yönelik gösterilecek olan olumlu tutumlar hem birey, hem de kurum açısından olumlu sonuçlara yol açabilir

Nitelikli bir öğretmenin alanı ile ilgili bilgi ve becerilere sahip olması tek başına yeterli olmamakta, bunun yanı sıra öğretmenlik mesleğine yönelik tutumunun da olumlu olması gerekmektedir (Çetin, 2006). 
Sabır, özveri ve sürekli çalışmayı gerektiren öğretmenlik mesleğini başarılı bir şekilde yerine getirmek için bu mesleği severek ve isteyerek yapmak gerekmektedir (K»rbıyık, 1995; Çapa ve Çil, 2000). Bu durum öğretmenlerin mesleklerine karşı taşıdıkları olumlu tutumla yakından ilgilidir. Öğretmenlerin mesleklerine karşı sahip oldukları tutumun, tüm tutumlar gibi sonradan öğrenilmesi öğretmen eğitiminin önemini ortaya koymaktadır (Can, 1987). Öğretmen adaylarına verilen eğitim, onların mesleklerine karşı olumlu tutum geliştirmelerini sağlamalıdır (Senemoğlu ve Özçelik, 1989; Johnson and Howell, 2005).

Literatürde öğretmenlik mesleğine yönelik tutumla ilgili yapılan araştırmaların bazıları şu çalışmalardır; Şimşek (2005) yapmış olduğu araştırmada, mezun olunan fakülte değişkeninin, öğretmen adaylarının öğretmenlik mesleğine yönelik tutumlarına bir etkisi olmadığını belirtmiş ve eğitim fakültesi öğrencileri ile fen-edebiyat fakültesi mezunlarının öğretmenlik mesleğine yönelik tutumlarında anlamlı bir farklılığın olmadığ sonucuna varmıştır. Bu çalışmada elde edilen sonuca paralel olarak Erdem Gezer ve Çokadar (2005), Pamukkale Üniversitesi Orta Öğretim Fen- Matematik ve Sosyal Alanlar Öğretmenliği Tezsiz Yüksek Lisans öğrencilerinin öğretmenlik mesleğine yönelik tutumlarını inceledikleri çalışmalarında, tezsiz yüksek lisans programına devam eden fen-edebiyat fakültesi mezunu öğretmen adaylarının öğretmenlik konusunda eğitim fakültesine devam eden lisans öğrencileri gibi olumlu tutuma sahip olduklarını belirtmişlerdir. Bu çalışmalarda ortaya çıkan sonucun aksine Yumuşak ve diğer (2006), genel olarak fen-edebiyat fakültesi mezunları ile eğitim fakültesi öğrencilerinin öğretmenlik mesleğine yönelik tutumlarının olumlu olduğunu ancak tutum puanları açısından iki grup arasında, eğitim fakültesi öğrencilerinin lehinde anlamlı bir fark olduğunu ifade etmişlerdir. Öğretmen adaylarının öğretmenlik mesleğine yönelik görüşleri, adayların bir yandan öğretmenliğe bağladıkları değerlere dikkat çekmesi, bir yandan da öğretmenlikteki başarılarını etkileyecek olması açısından oldukça önemlidir (Gürses ve diğer., 2005). Bununla birlikte Gök (2003), öğretmen yetiştirme programlarının en önemli görevinin öğretmenliğe ilişkin tutumların belirlenmesi, bunların öğretmen adaylarına nasıl kazandırılacağının saptanması ve bu işte ne derece başarılı olunduğunun değerlendirilmesi olduğunu ifade etmiştir. Verilerin değerlendirilmesi sonucunda öğretmen adaylarının öğretmenlik mesleğine yönelik tutumlarının, adayların öğretmenlik messleğini tercih etme nedenlerine göre farklılaştığı tespit edilmiştir. Hem eğitim fakültesi öğrencileri hem de fenedebiyat fakültesi mezunları arasından mesleği, öğretmen olmak istediği için seçenlerin tutum puanı ortalamalarının diğerlerinden daha yüksek olduğu tespit edilmiştir. Yumuşak ve diğer (2006) yapmış oldukları çalışmada elde ettikleri sonuç da bu bulguyu destekler niteliktedir. $\mathrm{Bu}$ sonuç, bir mesleği kendi isteğiyle seçenlerin o mesleğe karşı yüksek tutuma sahip oldukları yorumunu akla getirmektedir. Temel (2006), kişinin meslek seçiminde birden fazla etkenin rol oynadığını belirtmiş ve bu etkenlerden en önemlisinin bireyin bir meslekle ilgili kendi istek ve hayallerinin olduğunu ifade etmiştir.

Sunay (1996) tarafından yapılan araştırmada; MEB’e bağlı (1982 önciesi) yükseköğretim kurumlarından mezun öğretmenlerin öğretmenlik mesleğine yönelik tutum ve gözlem puanlarının aritmetik ortalamalarıyla YÖK'e bağlı yüksek öğretim kurumlarından mezun öğretmenlerin tutum ve gözlem puanları arasında önemli bir farklılık bulunmamıştır. 
Ülkemizde öğretmenlik mesleğine yönelik tutum konusunda geliştirilen ölçekler bulunmaktadır. Bunlardan biri Aşkar ve Erden (1987) tarafından geliştirilen "Öğretmenlik Mesleğine Yönelik Tutum Ölçeğì"dir. Bu ölçek, Orta Doğu Teknik Üniversitesi ve Hacettepe Üniversitesi eğitim fakültelerinde öğrenim görmekte olan öğrenciler üzerinde yapılan uygulamalarla geliştirilmiş, altı olumlu, dört olumsuz maddeden oluşan 10 maddelik, tek boyutlu Likert tipi bir ölçektir. Geliştirildiği tarihten günümüze kadar bazı araştırmalarda (Temel, 1990; Pehlivan 2004) kullanılmıştır. Bununla birlikte yakın zamanlarda öğretmenlik mesleğine yönelik çeşitli tutum ölçekleri de bazı araştırmacılar (Semerci ve Semerci 1999, Erkuş, Sanlı, Güven ve Bağlı 2000, Demirci 2002, Doğan 2002,) tarafından geliştirilmiş ve araştırmalarda kullanılmıştır.

Oral (2004) tarafindan yapılan "eğitim fakültesi öğrencilerinin öğretmenlik mesleğine ilişkin tutumları" başlıklı araştırmada Semerci ve Semerci (1999) tarafından "öğrencilerin öğretmenlik mesleğine yönelik tutumlarının ölçülmesi” amacıyla geliştirilen ölçek kullanılmıştır. Araştırma sonucunda cinsiyet, okunulan öğretmenlik programını tercih sırası, öğretmenlik mesleğini tercih nedeni değişkenleri açısından, eğitim fakültesi öğrencilerinin öğretmenlik mesleğine ilişkin tutumları arasında anlamlı düzeyde farklılık gözlenmiştir (Oral, 2004). Şenel ve arkadaşları (2004) tarafindan yapılan "öğretmenlik mesleğine yönelik tutum ve kişilik özellikleri arasındaki ilişki” başlıklı araştırma da, öğretmenlik mesleğine ilişkin tutumları ölçmek amacıyla Erkuş, Sanlı, Güven ve Bağlı (2000) tarafından geliştirilen tutum ölçeği kullanılmıştır. Araştırma sonucunda, ortaöğretim alan öğretmenliği tezsiz yüksek lisans programlarında öğrenim görmekte olan öğrencilerin, başkalarına güvenme, yardım alma, destekleyici, hoşgörülü, temkinli, dengeli, duyarlı, kararlı ve sosyal olma gibi olumlu kişilik özellikleriyle öğretmenlik mesleğine yönelik tutumlar arasında olumlu yönde anlamlı bir ilişkinin olduğu saptanmıştır (Şenel ve diğ., 2004) Çakır (2005) tarafından yapılan "Anadolu Üniversitesi Açık Öğretim Fakültesi İngilizce Öğretmenliği Lisans Programı ve Eğitim Fakülteleri İngilizce Öğretmenliği Lisans Programı Öğrencilerinin Mesleğe Yönelik Tutumları ve Mesleki Yeterlik Algıları" başlıklı araştırmada Erkuş, Sanlı, Güven ve Bağlı (2000) tarafından geliştirilen Öğretmenliğe ilişkin tutum ölçeği kullanılmıştır. Araştırma sonucunda Anadolu Üniversitesi Açık Öğretim Fakültesi İngilizce Öğretmenliği Lisans Programı ve Eğitim Fakülteleri İngilizce Öğretmenliği Lisans Programı Öğrencilerinin Mesleğe Yönelik Tutumları ve Mesleki Yeterlik Algıları konusunda ele alınan değişkenler açısından anlamlı bir farklılı̆ıı olmadığı bulunmuştur (Çakır, 2005).

Öğretmen Adaylarının Öğretmenlik Mesleğine ve Lisansüstü Eğitim Yapmaya Yönelik Tutumları başlığı altında şimdiye kadar öğretmen adaylarının öğretmenlik mesleğine yönelik tutumlarının ne denli önemli olduğunun yanı sıra bu anlamda yapılan çalışmalara ve öğretmenlik mesleğine yönelik geliştirilen tutum ölçeklerine yer vermeye çalı̧̧ık, bu noktadan sonra öğretmen adaylarının akademik kariyer ve lisansüstü eğitime yönelik tutumları üzerine yapılan çalışmalara ve bu durumun önemine değinmeye çalışacağız.

Kariyer kavramı, bireyin çalışma yaşamı boyunca herhangi bir iş alanında ilerlemesi, deneyim ve beceri kazanması (Erdoğmuş, 2003) olup değerler, davranışlar ve motivasyon kavramlarına odaklanmaktadır (Hall, 1994). Diğer bir ifadeyle kariyer, bir insanın herhangi bir iş alanında adım adım ve sürekli olarak ilerlemesi, deneyim ve beceri kazanmasıdır (Aydemir, 1995). 
Kariyer, bireyin yaşamı boyunca izlediği faaliyetlerle ilişkili bireysel olarak elde edilmiş davranışları, bireyin karşılaşabilecek olanakları, psikolojik ödülleri ve daha iyi bir yaşam biçimini ifade eder (Aytaç, 1997).

Kurumlarda yaşanan hızlı değişimler hem kurumların hem de çalışanların kariyer kavramına bakışını değiştirebileceğinden, ilk kariyer adımlarının atıldığı eğitim hayatının da bu değişimlerden etkilenmesi beklenmektedir. Kariyerin değişen özelikleri, fark yaratan bilgi, beceri, yetenek ve tutumlara sahip çalışanlara, kendini bir kuruma adayan çalışanlardan daha fazla önem vermektedir. Bireylerin kariyerlerini bu faktörleri göz önünde bulundurarak yapılandırması, kurumların da insan faktörünü akılcı ve doğru bir şekilde kullanması,üniversite camiasında öğrenci ve akademisyenlerin tutumlarında ve onlardan kaynaklanan problemlerin çözümüne katkıda bulunacaktır. Bu nedenle eğitim sistemlerinin de uzmanlıklara ve geliştirmeyi amaç edinmiş yetkinliklere dayalı yapılandırılması gerekmektedir (Özer, 2001).

Lisansüstü öğretim, bilim alanında yetkinleşme ve uzmanlaşma açısından dünyada bir zorunluluk haline gelmiştir. İş gücü piyasalarının, birçok alanda olduğu gibi kendisi için işgücünü hazırlayan eğitim kurumları üzerinde etkileri açıkça görülmeye başlanmıştır. İş gücü piyasasında kendilerine yer elde etmeye çalışan bireyler, aranan bir işgören olabilmek için işgücü talebinde sürekli uzayan kuyruğun başına geçme çabası içindedirler. Lisans düzeyinde mezun sayısının artması, bireyleri daha ileri eğitim düzeylerine ve daha farklı niteliklerle donanmaya yönlendirmektedir. Bu anlamda lisansüstü öğretim bireyin gellecekteki gelirini ve sosyal statüsünü artırmaya yönelik yaptığı bir yatırım olarak görülebilir. Öğretmen adayları için de durum böyledir.

Öğretmenlerin, lisans sonrasında da iş başında eğitimini sürdürmelerinde uzmanlaşma, kendi niteliğini yükseltme, eğitim alanındaki yenilikleri takip etme ve sınıf ortamında bunları uygulayabilme bakımından lisansüstü eğitimin önemi büyüktür (Alabaş, 2011).

Öğretmenlerin mesleki ve kişisel gelişimlerini sağlamak, böylece okul ve sınıf içi uygulamaları araştırma problemi haline getirip sonuçlarını paylaşmada,lisansüstü eğitim çalışmaları yol gösterici olmaktadır.

Alhas (2006) tarafından yapılan "lisansüstü eğitim yapmakta olan Milli Eğitim Bakanlığ1 öğretmenlerinin lisansüstü eğitime bakış açıları (Ankara ili örneği)" başlıklı yüksek lisans çalışmasında anket yardımıyla toplanan veriler sonucunda öğretmenlere lisansüstü eğitimin kazandırdı̆̆ 1 beceriler sırasıyla "akademik çalışmalar için dayanak oluşturması, bilimsel araştırma ile bilgiye erişme, değerlendirme ve yorumlama becerisi geliştirme, mesleki çevre ve öğrenciler ile iyi ilişkiler kurma, çevrenin, okulun ve sınıfın eğitim-öğretim problemlerini bilimsel yollarla çözmede yardımcı olmak" şeklinde ortaya konulmuştur.

Öğretmenlerin lisansüstü eğitimi tercih etmelerinde, akademik personel olma istekleri, kişisel gelişim ve meslekî kariyer kazanma isteklerinden sonra gelmiştir. Başer vd. (2005) tarafından yüksek lisans yapan öğretmenlere yönelik yapılan bir araştırmada da benzer sonuca ulaşılmış, ancak Oluk ve Çolak'ın (2005) lisansüstü eğitim alan öğretmenlere yönelik yaptığı araştırma sonucuna benzerlik göstermemiştir. Başer vd.(2005) araştırmalarında yüksek lisans eğitimi alan öğretmenlerin \%16,7'sinin akademik kariyer için lisansüstü eğitim aldıkları sonucuna 
ulaşırken, Oluk ve Çolak (2005)araştırmalarına katılan bütün lisansüstü eğitim alan öğretmenlerin, akademik kariyer ve üniversitelerde görev almayı lisansüstü eğitime başlama sebebi olarak belirttikleri sonucuna ulaşmıştır. Araştırmada öğretmenlerin özellikle kişisel gelişimleri için lisansüstü eğitimi tercih ettikleri ortaya çıkmıştır. Kişisel gelişimleri ile ilgili alanda kendisini geliştirme, eğitim sorunlarına çözüm üretme, bilimsel merak, eğitim programlarında yetkinlik, yenilikleri takip etme ve yan alan isteği görüşleri ortaya çıkmıştır.

Elde edilen bu bulgu Kara ( 2008) tarafından yapılan çalışmanın bulguları ile benzerlik göstermektedir. Kara, matematik öğretmenlerinin lisansüstü eğitim deneyimleri ve okul yaşantılarına yansımalarını incelediği çalışmasında, lisansüstü eğitim yapan matematik öğretmenlerinin aldıkları lisansüstü eğitimin kişisel ve mesleki gelişimlerine katkısını,kendi alanlarıyla ya da eğitim-öğretim ile ilgili gelişmeleri internet ortamında makaleokuyarak veya gazete okuyarak takip etme, lisansüstü eğitimin öğretmenler arasındasosyalleşmeyi sağlaması, öğretmenlerin birbirlerinin geliştirmelerine yardımcı olması,yansıtıcı düşünme becerilerine sahip olmaları şeklinde ifade ettikleri sonucunaulaşmıştır.

Öğretmenlerin kaydoldukları programı tercih etme gerekçesi olarak "alanıyla ilgili bilgi sahibi olmak ve yeni öğretim yöntem ve tekniklerini tanıma, alanıyla ilgili bilgileritakip etme" öne çıkan sebepler olmuştur. Bu da öğretmenlerin lisansüstü programlarından beklentilerinin hangi konularda yoğunlaştığını göstermektedir. Öğretmenlerin kaydoldukları programın beklentilerini karşılaması ile ilgili olarak daaraştırmaya katılan öğretmenlerin yarıdan bir fazlasının kaydolduğu programın beklentilerini karşılamadığı şeklinde görüş belirttiği sonucuna ulaşılmıştır. Bu sonuçlisansüstü eğitime olan beklentinin gerçekleşme durumunu göstermesi açısındanönemlidir. Yapılan araştırmalarda genellikle öğretmen adaylarının lisansüstü eğitim almaya karşı olumlu tutum ve isteklilik sergiledikleri Dönmez vd. (2012), Şaşmaz Örenvd. (2012), İlhan vd, (2012), Koksalan vd. (2010), Ünal ve İlter, (2010), Erkılıç (2007), mesleğe başlayan öğretmenlerin ise lisansüstü eğitim alma konusunda olumlu tutumlar yanında olumsuz tutumlar da sergiledikleri görülmektedir. Doğusan (2003) tarafından“İlköğretim okulu yönetici ve öğretmenlerinin, öğretmenlerin lisansüstü öğrenimi konusundaki tutumları (Kırıkkale il örneği)" başlıklı yüksek lisans tezinde Kırıkkale ilinde toplam 299 yönetici ve öğretmenin lisansüstü eğitime bakış açısı ölçek yardımıyla belirlenmiş, buna göre yönetici ve öğretmenlerin lisansüstü öğrenime ilişkin geneltutumları, lisansüstü öğrenime giriş koşulları, lisansüstü öğrenim süreci ve lisansüstüöğrenim sonrası ile ilgili olumsuz tutum sergilemişler, lisansüstü öğrenimin önemikonusunda ise kararsız kalmışlardır. Adıgüzel ve İpek (2010) tarafından ilköğretim birinci ve ikinci kademe öğretmenlerinin lisansüstü eğitime ilişkin beklentileri üzerineyapılan çalışmada lisansüstü eğitim "genel yarar, kişisel gelişim, maddi çıkar" boyutlarında olumlu bulunurken olumsuz beklentilerin de bulunduğu sonucunaulaşılmıştır. Ülkemiz dışındaki öğretmenlerin lisansüstü eğitim yapma nedenleri arasında da kendini geliştirme ile yeni yöntem ve teknikleri öğrenme öne çıkmaktadır. (Kyriacou \& Kunc, 2007; Bertram, Mthiyane \& Mukeredzi, 2012).

Yapılan çalışmalar ışığında lisansüstü eğitime yönelik öğretmen adaylarının tutumlarının çoğunlukla olumlu yönde olduğu kanısına varılmaktadır. 


\section{Sonuç}

$\mathrm{Bu}$ literatür taramasıyla araştırmamızda öğretmen adaylarının öğretmenlik mesleğini tercih sebepleri, lisansüstü eğitim ve öğretmen adaylarının lisansüstü eğitime yönelik tutumları üzerine yapılan araştırmalar derlenmiştir.

Hızla ilerleyen ve küreselleşen dünyada pek çok değerin değiştiği ya da farklı yaklaşımların ortaya çıktığı görülmektedir. Geleceğe sağlam adımlarla ilerlemesi istenilen gençler için akademik başarı ve lisansüstü eğitim artık daha da önem gerektirmekte ve özen istemektedir. Son zamanlarda yükselen bir trend haline gelen lisansüstü eğitim öğretmen ve öğretmen adaylarının da dikkatini çekmektedir.

Araştırmalar, öğretmenlerin kişisel ve mesleki gelişimleri ile ilgili sahip olmaları beklenilen niteliklerle, lisansüstü eğitimle öğretmenlere kazandırılması amaçlanan beceriler arasında uyum olduğu ortaya koymuştur. Bununla birlikte öğretmenlerin kendilerini yenileme, bilimsel ve teknolojik gelişmelerden haberdar olma ve daha verimli olmak için lisansüstü eğitim yaptıklarına dair sonuçlar öne çıkmaktadır. 


\section{REFERENCES}

- Adıgüzel, İ, ve İpek, C. (2011). İlköğretim Birinci ve İkinci Kademe Öğretmenlerinin Lisansüstü Eğitime İlişkin Beklentileri. 5-7 Mayıs 2011 Sivas. 10. Ulusal Sınıf Öğretmenliği Eğitimi Sempozyumu'nda sunulmuş bildiri.

- Alhas, A., (2006) Lisansüstü Eğitim Yapmakta Olan Milli Eğitim Bakanlı̆ğ Öğretmenlerinin Lisansüstü Eğitime Bakış Açıları, Yüksek lisans tezi, Gazi Üniversitesi, Eğitim Bilimleri Enstitüsü, Ankara.

- Akpınar, Y., (2003) Öğretmenlerin Yeni Bilgi Teknolojileri Kullanımında Yükseköğretimin Etkisi: İstanbul Okulları Örneği, Turkish Online Journal of Educational Tecnology, 2, 11.

- Aslan, K. (2003). Eğitim fakültelerinin yeniden yapılandırılmalarına ilişkin bir değerlendirme. Balıkesir Üniversitesi Sosyal Bilimler Enstitüsü Dergisi, 6(9), 23-37.

- Aytaç, S. (1997). Çalışma Yaşamında Kariyer, Epsilon Yayınları, İstanbul.

- Bakioğlu, A. ve Gürdal, A., (2001) Lisansüstü Tezlerde Danışman ve Öğrencilerin Rol Algıları: Yönetim İçin Göstergeler, Hacettepe Üniversitesi Eğitim Fakültesi Dergisi , 21, 9-18.

- Bastick, T. (2000). Why teacher trainees choose the teaching profession? Comparing trainees in metropolitan and developing countries. International Review of Education, 46(3/4), 343-349.

- Behymer, J., \& Cockriel, I. W. (1988). Career choice conflict. Journal of Career Development, 15(2), 134-140.

- Bertram C., Mthiyane N. and Mukeredzi T. (2012). 'It will make me a real teacher': Learning experiences of part time PGCE students in South Africa. International Journal of Educational Development. [Internet: 25 Kasım 2012 http://dx.doi.org/ 10.1016/j.ijedudev.2012.10.001

- Brown, M. M. (1992) Caribbean first-year teachers' reasons for choosing teaching as a career. Journal of Education for Teaching, 18(2), 185-195.

- Boz, Y., ve Boz, N. (2008). Kimya ve matematik öğretmen adaylarının öğretmen olma nedenleri. Kastamonu Eğitim Dergisi, 16(1), 137-144.

- Burgaz, B. ve Şentürk, İ. (2007), Yüksek Lisans Tez Danışımanlarının iletişim Davranışlarına İlişkin Danışman ve Danışan Görüşleri. III. Lisansüstü Eğitim Sempozyomu Bildiriler Kitabı, Eskişehir, Anadolu Üniversitesi, Eğitim Bilimleri Enstitüsü, 133-144.

- Bülbül, T., (2003) Ankara Üniversitesi Eğitim Bilimleri Fakültesinde Görev Yapan Öğretim Üyelerinin Lisansüstü Öğretime Öğrenci Seçme Sürecine İlişkin Görüşleri, Ankara Üniversitesi Eğitim Bilimleri Fakültesi Dergisi, 36.

- Bümen, N. T., (2006) Doktora Eğitimi Yapan Öğrencilere Yönelik Yürütülen "Öğretimde Planlama ve Değerlendirme" ile "Gelişim ve Öğrenme" Derslerinin Değerlendirilmesi, Kuram ve Uygulamada Eğitim Bilimleri Dergisi, 6, 9-43.

- Can, G. (1987). Öğretmenlik meslek anlayışı üzerine bir araştırma (Ankara Okullarında). Anadolu Üniversitesi Eğitim Fakültesi Dergisi, 1 (2), 159-170.

- Chuene, K., Lubben, F. \& Newson, G. (1999) The views of pre-service and novice eachers on mathematics teaching in South Africa related to their educational experience. Educational Research, 41, 23-34.

- Çakır, Ö. (2005). Anadolu üniversitesi açıköğretim fakültesi ingilizce öğretmenliği lisans programı (IÖLP) ve eğitim fakülteleri ingilizce öğretmenliği lisans programı 
öğrencilerinin mesleğe yönelik tutumları ve mesleki yeterlik algıları. İnönü Üniversitesi Eğitim Fakültesi Dergisi, 9 (6), 27-42.

- Çelik, E., (2007) Etkin ve Kolay Kullanımlı Bir Lisansüstü Eğitime Geçiş Kapısının Tasarımı ve Gerçekleștirilmesi, Yüksek lisans tezi, Gazi Üniversitesi, Fen Bilimleri Enstitüsü, Ankara.

- Çeliköz, N., Çetin, F. (2004). Anadolu öğretmen lisesi öğrencillerinin öğretmenlik mesleğine yönelik tutumlarını etkileyen etmenler. Milli Eğitim Dergisi, 162, 136-145.

- Çelikten, M., Şanal, M., ve Yeni, Y. (2005). Öğretmenlik mesleği ve özellikleri. Erciyes Üniversitesi Sosyal Bilimler Enstitüsü Dergisi, 19(2), 207-237.

- Çetin, Ş. (2006). Öğretmenlik mesleği tutum ölçeğinin geliştirilmesi (geçerlik ve güvenirlik çalışması). Gazi Üniversitesi Endüstriyel Sanatlar Eğitim Fakültesi Dergisi, 18, 28-37.

- Demir, C. (2007) Lisansüstü Eğitim Alan Öğrencilerin Eğitim-Öğretim Sürecinden Beklentileri ve Beklentilerinin Gerçekleşme Düzeyi. III. Lisansüstü Eğitim Sempozyomu Bildiriler Kitabı, Eskişehir, Anadolu Üniversitesi, Eğitim Bilimleri Enstitüsü, 195-207.

- Demirtaşl1, N.Ç., (2002) Lisansüstü Eğitim Programlarına Girişte Lisansüstü Eğitimi Giriş Sınavı (LES) Sonucunun ve Diğer Ölçütlerin Kullanımına İlişskin Bir Tarama, Ankara Üniversitesi Eğitim Fakültesi Dergisi, 35, 61-70.

- Erdem, A.R., Gezer, K., Çokadar, H. (2005). Ortaöğretim fen-matematik ve sosyal alanlar öğretmenliği tezsiz yüksek lisans öğrencilerinin öğretmenlik mesleğine ilişkin tutumlar1. 14. Ulusal Eğitim Bilimleri Kongresi Bildirileri, PAÜ. Denizli, 471-47

- Foster, T. \& Newman, E. (2005). Just a knock back? Identity bruising on their route to becoming a male primary school teacher. Teachers and Teaching: Theory and Practice, 11(4), 341-358.

- Freire, P. (1998). Teachers as cultural workers: Letters to those who dare to teach. Colorado: Westview Pres

- Giroux, H. A. (1988). Teachers as intellectuals. Toward a critical pedagogy of learning. New York, NY: Bergin \& Garvey.

- Gök, F. (2003). Hizmet öncesi ve hizmet içi öğretmen yetiştirme. http://www.egitimsen.org.tr/ belgeler/ogretmenyetistirme.doc (15.12.2010).

- Gürses, A., Doğar, Ç., Özkan, E., Açıkyıldız, M., Bayrak, R., Yalçın, M. (2005). Alan öğretmeni yetiştirmede tezsiz yüksek lisans eğitiminin sonuçlarının değerlendirilmesi. S.D.Ü. Burdur Eğitim Fakültesi Dergisi, 9, 1-10.

- Güven, İ. ve Tunç, B. (2007). Lisansüstü Öğretim Öğrencilerinin Akademik Sorunlar1 (Ankara Üniversitesi Eğitim Bilimleri Enstitüsü Örneği), 173, 157-171.

- Kırbıyık, H. (1995). Fen ve matematik öğretmenlerinin eğitimi. Uluslararası Dünya Öğretmen Eğitimi Konferansı Bildirileri, 27 Ağustos-2 Eylül 1995. Ankara, 176-186

- Kyriacou C., Kunc R. (2007). Beginning teachers' expectations of teaching. Teaching and Teacher Education. 23 1246-1257 [Internet: 5 Kasım 2012 http://dx.doi.org/ 10.1016/j.tate.2006.06.002

- Köksalan, B. İlter, İ. ve Görmez, E. (2010). Sınıf Öğretmeni Adaylarının SosyoKültürel Özellikleri ve Lisansüstü Eğitim İsteklilikleri Üzerine Bir Çalışma (Fırat, Erzincan ve İnönü Üniversitesi Sınıf Öğretmenliği ABD Örneği). Ahi Evran Üniversitesi Eğitim Fakültesi Dergisi, 11 (3): 277-299

- Kuzu, A. ve Becit, G. (2007) Öğretmenlerin Lisansüstü Eğitimde Karşılaştıkları Sorunlar ve Çözüm Önerileri. III. Lisansüstü Eğitim Sempozyomu Bildiriler Kitab1, Eskişehir, Anadolu Üniversitesi, Eğitim Bilimleri Enstitüsü, 380-388. 
- Mulholland, J. \& Hansen, P. (2003). Men who become primary school teachers: An early portrait. Asia-Pacific Journal of Teacher Education, 31(3), 213-224.

- Oral, B., 2000. Öğretmen Adaylarının Algılarına Göre İlköğretim Sinıf Öğretmenlerinin Dönüt ve Düzeltme Davranışları, Eurasian Journal of Educational Research, 2.

- Özbek, R. (2007). Öğretmen adaylarının öğretmenlik mesleğini tercih etmelerinde kişisel, ekonomik ve sosyal faktörlerin etkililik derecesine ilişkin algıları. Fırat Üniversitesi Sosyal Bilimler Dergisi, 17(1), 145-160

- Özer, Y. (2001). İnsan Kaynaklarında Yeni Açılımlar: Ne Yalanı Ama, (Sezik, N.), Hayat Yayınları, İstanbul.

- Papanastasiou, C., \& Papanastasiou, E. (1998). What influences students to choose the elementary education major: The case of Cyprus. Mediterranean Journal of Educational Studies, 3, 35-45.

- Parr, M., Gosse, Douglas, \& Allison, J. (2008). The professional journey of male primary teachers: Experiences and perceptions of entering into a "sacred female space". The International Journal of Diversity in Organizations, Communities and Nations, 7(6), 257-265.

- Saban, A. (2003). A Turkish profile of prospective elementary school teachers and their views of teaching. Teaching and Teacher Education, 19, 829-846.

- Semerci, N., (2005). Problem Temelli Öğrenme ve Öğretmen Yetiştirme, Milli Eğitim Dergisi, 33.

- Senemoğlu, N., Özçelik, D., A. (1989). Öğretmen adaylarına "öğretmenlik bilgisi" kazandırma bakımından fen-edebiyat ve eğitim fakültelerinin etkililiği, Çağdaş Eğitim Dergisi, 142, 18-21.

- Semerci, N., (2005). Problem Temelli Öğrenme ve Öğretmen Yetiştirme, Milli Eğitim Dergisi, 33.

- Sunay, H. (1996) Orta öğretim kurumlarına öğretmen yetiştirmede üniversite öğretiminin önemi. Eğitim Yönetimi. 2 (2) 279-294.

- Şenel, T., Nas, S. E. ve Yıldırım, N. Kimya Öğretmen Adaylarının Lisansüstü Eğitim Yapma Nedenleri Ve Beklentileri. I. Kimya Eğitimi Kongresi, Haziran 2007, İstanbul.

- Şaşmaz Ören, F., Yılmaz, T. ve Güçlü, M. (2012). Öğretmen Adaylarının Lisansüstü Eğitime Yönelik Görüşlerinin Analizi, Eğitim ve Öğretim Araştırmaları Dergisi, 1 (2):189-201

- Temel, A. (2006). Alan ve meslek seçiminde dikkat edilmesi gereken hususlar. http://www.maltepe.edu.tr/haberler/mesleksecimi.doc. (19.12.2010).

- Turgut, F., (1987) Eğitimde Lisansüstü Eğitim, Hacettepe Üniversitesi Eğitim Fakültesi Dergisi, 2.

- Tuzcu, G., (2003) Lisansüstü Öğretim İçin Yurtdışına Öğrenci Göndermenin Planlanması. Milli Eğitim Dergisi, 160.

- Yapıcı, M.(2003) Toplam Kalite Yönetimi. V. Ulusal Makine Mühendisliği ve Eğitimi Sempozyumunda sunulan poster, , TMMOB Makine Mühendisleri Odası.

- Yumuşak, A., Aycan, N., Aycan, Ş., Çelik, F., Kaynar, H. Ü. (2006). Muğla üniversitesi tezsiz yüksek lisans programı ile eğitim fakültesi lisans programı öğrencilerinin öğretmenlik mesleğine yönelik tutum ve endişelerinin karşılaştırılması 15. Ulusal Eğitim Bilimleri Kongresi Bildiri Özetleri, 13-15 Eylül 2006, MÜ. Muğla, 266. 